\title{
Inventarisasi Tanaman Obat di Lokasi Pembangunan Kampus Universitas Sulawesi Barat (Studi Pendahuluan)
}

\author{
Phika Ainnadya Hasan ${ }^{* 1}$, Firman $^{2}$, Nurhidayah ${ }^{3}$ \\ 1,2,3 Universitas Sulawesi Barat; \\ e-mail: ${ }^{1}$ phkhasan@gmail.com, ${ }^{2}$ firman @ unsulbar.ac.id, ${ }^{3}$ nurhidayah.n@gmail.com
}

\begin{abstract}
Abstrak
Sejak tahun 2015 universitas sulawesi barat sedang melaksanakan pembangunan kampus. Pembangunan ini melibatkan pembukaan hutan menjadi lahan terbuka. Ini akan menyebabkan penurunan keanekaragaman hewan dan tumbuhan di daerah tersebut. Hingga saat ini belum ada data dari penelitian sebelumnya mengenai keanekaragaman hewan dan tumbuhan di lokasi pembangunan kampus universitas sulawesi barat. Data ini menjadi penting untuk mengetahui perubahan keankeragaman di wilayah tersebut. Penelitian ini bertujuan untuk menghitung komposisi jenis tanaman obat di lokasi pembangunan kampus universitas sulawesi barat. Pengumpulan data dilakukan dengan metode angket. Hasil menunjukan bahwa terdapat tujuh jenis tanaman obat, yaitu Muntingia calabura, Ageratum conizoides, Solanum lycopersicum, Psidium guajava, Jatropha curcas, Sauropus androgynous, Phyllanthus niruri, Coleus scutellaroides dan Euphorbia hirta.
\end{abstract}

Kata kunci: tanaman obat, dampak negatif pembangunan, keanekaragaman hayati

\section{PENDAHULUAN}

Universitas sulawesi barat merupakan perguruan tinggi yang berdiri sejak tahun 2013. Sebagai satu-satunya universitas negeri di provinsi sulawesi barat, universitas sulawesi barat memegang peranan yang sangat penting. Namun demikian, demi peningkatan kualitas pendidikan, universitas sulawesi barat melakukan pembangunan kampus. Berlokasi di Padha-padhang, Kabupaten Majene. Pembangunan ini memiliki luas 30 hektar dan rencananya akan selesai tahun 2024.

Pembangunan dapat diartikan sebagai perubahan yang direncanakan. Umumnya tujuan pembangunan selalu postif. Kualitas suatu negara dapat digambarkan dari kualitas pembangunannya. Negara maju memiliki pembangunan yang lebih baik daripada negara berkembang. Hal juga terjadi pada kualitas perkotaannya. Jakarta adalah kota paling berkembang di Indonesia. Oleh karena itu, Jakarta dianggap sebagai kota paling maju di Indonesia. Tetapi seperti dua sisi koin yang berbeda, pembangunan memiliki dampak positif berupa peningkatan kualitas hidup, namun berdampak pada penurunan kualitas lingkungan. Dampak negative ini akan mempengaruhi kualitas kehidupan dalam jangka panjang.

Salah satu dampak negative dari pembangunan adalah penurunan keanekaragaman hayati (Widiyati dan Prihadi, 2007). Indonesia terkenal dengan jumlah keanekaragaman hayatinya di dunia. Salah satu keanekaragaman hayati penting di Indonesia adalah tanaman obat. Tanaman obat adalah tanaman yang dapat digunakan untuk menyembuhkan beberapa jenis penyakit. Penggunaan tanaman obat di Indonesia sudah berlangsung sejak zaman dahulu bahkan telah menjadi budaya. Penelitian mengenai tanaman obat di Indonesia telah banyak dilakukan (Jumiarni dan Oom, 2017; Nurrani, 2013; Syamsiah, 2014). Saat ini penelitian tanaman obat bukan lagi berfokus pada pembuktian khasiat tanaman obat, tetapi pemanfaatan ekonomi dan pelestarian tanaman tersebut. Hal ini telah dilakukan oleh kementerian perdagangan (2017) dan organisasi PEKAIndonesia (2015) dalam bentuk buku.

Dalam proses pembangunan 30 hektar kampus universitas sulawesi barat, tentu saja ini akan melibatkan penebangan pohon dan pembukaan lahan. Dibutuhkan data awal mengenai keanekaragaman hayati

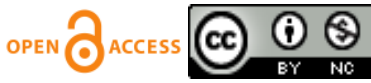


wilayah tersebut untuk melihat fluktuasi keanekaragaman hayati dimasa depan. Oleh karena itu, penelitian ini penting untuk dilakukan. Namun penelitian ini hanya berfokus pada tanaman obat. Tanaman ini dipilih karena budaya masyarakat sulawesi barat masih sangat kental dengan hal-hal alamiah. Data ini menjadi bahan evaluasi dimasa yang akan datang.

\section{METODE PENELITIAN}

\subsection{Waktu dan Tempat Pengamatan}

Penelitian ini dilaksanakan pada bulan Agustus 2019 di lokasi pembangunan kampus universitas sulawesi barat yang terletak di desa padha-padhang, Kecamatan Banggae Timur, Kabupaten Majene, Provinsi Sulawesi Barat.

Penelitian ini menggunakan metode angket. Angket di sebarkan ke masyarakat yang tinggal di sekitar lokasi pembangunan kampus. Angket tersebut berisi pertanyaan tentang (1) waktu dimulainya penggunaan tanaman obat, (2) waktu penggunaan tanaman obat, dan (3) jenis tanaman obat yang digunakan [lampiran]. Tanaman yang tertulis dalam angket selanjutnya dicari di lokasi pembangunan kampus menggunakan metode systematic plot sampling. Dengan ukuran plot $5 \times 5$ meter sebanyak 3 plot dengan jarak antar plot 5 meter. Lokasi pembangunan kampus dapat dilihat pada gambar 1.

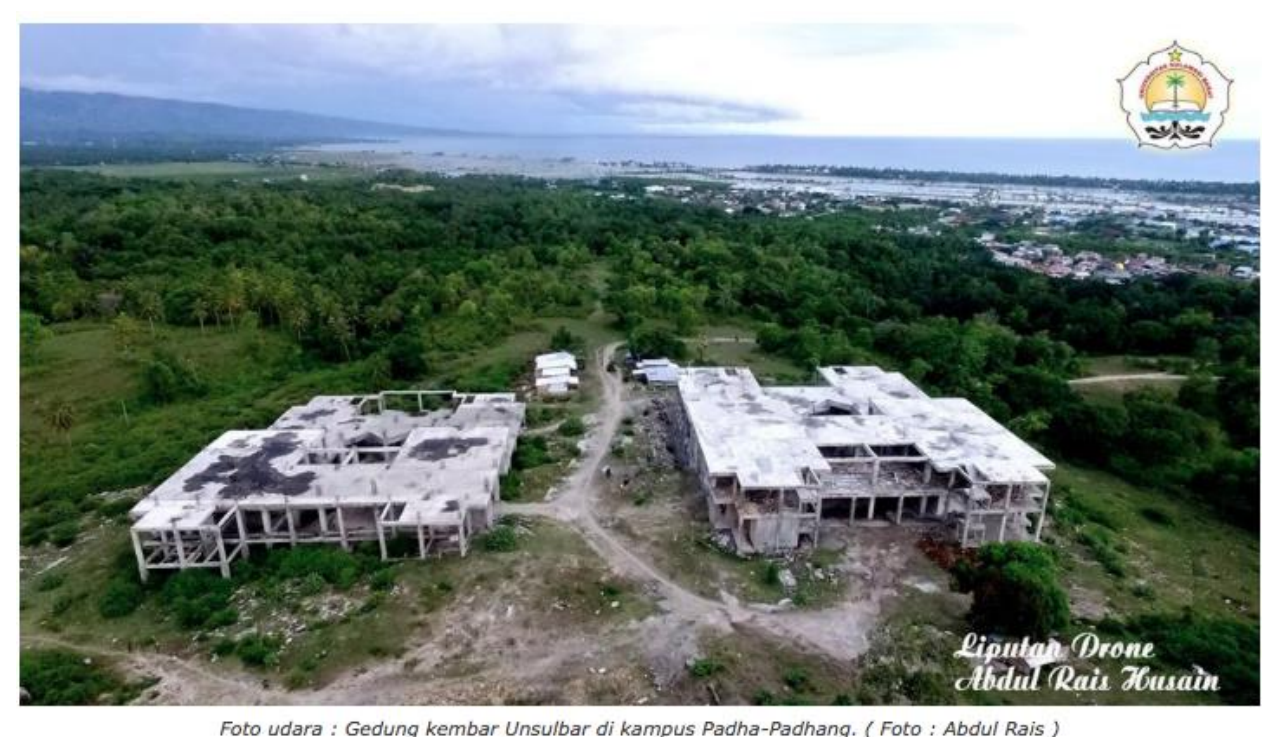

Gambar 1 Lokasi Penelitian

\section{HASIL DAN PEMBAHASAN}

Terdapat delapan jenis tanaman yang biasa digunakan oleh masyarakat yang tinggal di sekitar area pembangunan kampus, yaitu: Kersen (Muntingia calabura), Angguni (Ageratum conizoides), Tomat (Solanum lycopersicum), Jambu (Psidium guajava), Jarak (Jatropha curcas), Katuk (Sauropus androgynous), Meniran (Phyllanthus niruri), Miyana (Coleus scutellaroides) dan Patika Kebo (Euphorbia hirta). 
https://jurnal.unsulbar.ac.id/index.php/saintifik

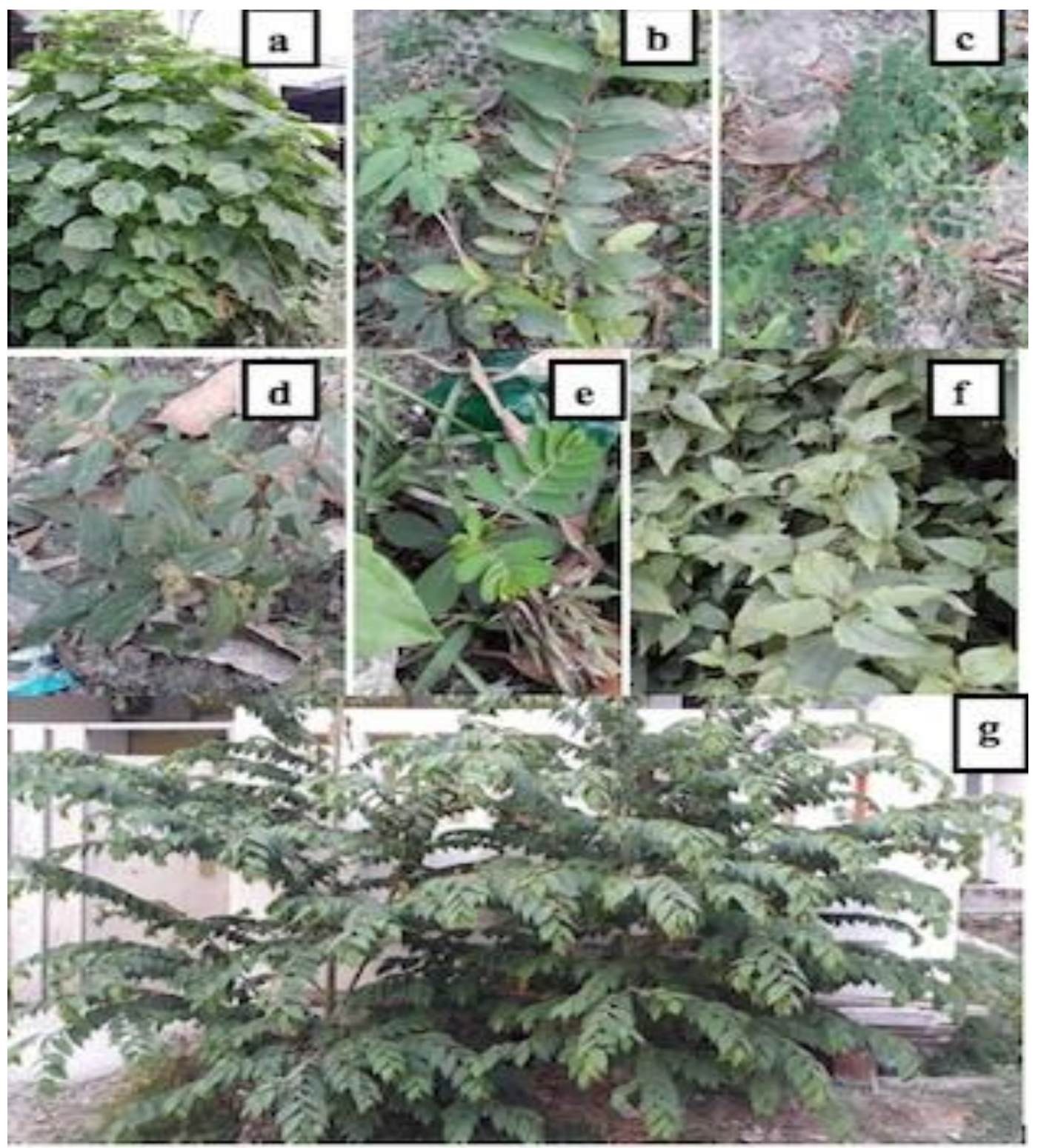

Gambar 2 Beberapa jenis tanaman obat yang ditemukan a). Jarak (Jatropha curcas), b). Jambu (Psidium guajava), c). Katuk (Sauropus androgynous), d). Patikan Kebo (Euphorbia hirta), e). Angguni (Ageratum conizoides), f). Meniran (Phyllanthus niruri), dan

g). Kersen (Muntingia calabura).

Penelitian tentang tanaman obat telah banyak dilakukan di Indonesia. Sebagian besar dari mereka bertujuan untuk mencatat jenis tanaman obat (Jumarni dan Oom, 2017), menjadi referensi untuk pengelolaan kesejahteraan masyarakat dan keberlanjutan kehidupan berbasis daerah (Nurrani, 2013), dan sebagai data dasar untuk pengembangan penelitian berkelanjutan di bidang tanaman obat (Syamsiah, 2014). Penelitian tentang tanaman obat di Kabupaten Majene telah dilakukan oleh Syamsiah (2014). Ada 45 jenis tanaman medis yang ditemukan olehnya, 5 di antaranya juga digunakan oleh penduduk kami tetapi hanya jarak (Jatropha curcas) yang ditemukan di area pembangunan kampus. Perbedaan ini disebabkan oleh perbedaan jumlah angket yang digunakan dan luas area yang digunakan. Sebagai studi pendahuluan, angket yang kami gunakan hanya 10 dan area yang kami jelajahi hanya 10 ha dari total luas pengembangan, yaitu 30 hektar.

Tanaman obat adalah tanaman yang dapat digunakan untuk menyembuhkan beberapa jenis penyakit. Ini telah dilakukan sejak zaman kuno. Beberapa dari mereka telah diuji secara ilmiah di era saat ini. Seperti 
potensi aktivitas antibakteri pala (Myristica fragrans) pada Escherichia coli (Arrizqiyani et al. 2018), Pandanus amaryllifolius sebagai agen antibakteri (Mardiyaningsih dan Resmi 2014), dan bawang merah (Allium cepa) sebagai antimikroba (Octaviani et al. 2019). Tanaman ini dapat digunakan sebagai obat karena mengandung metabolit sekunder. Seperti pada pala yang mengandung saponin, flavonoid, alkaloid dan terpenoid (Arrizqiyani et al. 2018). Metabolisme sekunder adalah zat yang diproduksi oleh tanaman yang umumnya berfungsi melindungi diri, tidak digunakan untuk pertumbuhan, tetapi zat ini bisa menjadi obat bagi manusia. Adapun fungsi dari masing-masing tanaman dapat dilihat pada tabel 1.

Tabel 1 Perbandingan jenis serangga penyerbuk sawi dan tomat

\begin{tabular}{|c|l|c|l|}
\hline No & \multicolumn{1}{|c|}{ Jenis Tanaman } & $\begin{array}{c}\text { Bagian yang } \\
\text { digunakan }\end{array}$ & \multicolumn{1}{|c|}{ Manfaat } \\
\hline 1 & Muntingia calabura & Daun & Batuk \\
\hline 2 & Angguni (Ageratum conizoides) & Daun & Penyakit dalam \\
\hline 3 & Tomat (Solanum lycopersicum) & Buah & $\begin{array}{l}\text { Sumber vitamin dan } \\
\text { digunakan sebagai masker } \\
\text { wajah }\end{array}$ \\
\hline 4 & Miana (Coleus scutellaroides) & Daun & Batuk \\
\hline 5 & guava (Psidium guajava), & Daun & Diare \\
\hline 6 & Jarak (Jatropha curcas & Daun & Demam dan rematik \\
\hline 7 & Katuk (Sauropus androgynous) & Daun & Melancarkan ASI bagi ibu \\
\hline 8 & Meniran (Phyllanthus niruri) & Daun & Obat jerawat \\
\hline 9 & Patikan Kebo (Euphorbia hirta) & Daun & Asma \\
\hline
\end{tabular}

\section{KESIMPULAN}

Hasil penelitian menunjukkan bahwa tidak ada jenis tanaman obat tertentu yang digunakan oleh masyarakat di sekitar area konstruksi kampus. Tumbuhan yang digunakan sama dengan masyarakat lain di Indonesia. Terdapat empat belas jenis tanaman obat yang digunakan oleh penduduk, tetapi hanya tujuh jenis tanaman obat yang ditemukan di area pembangunan kampus. Ini adalah Kersen (Muntingia calabura), Angguni (Ageratum conizoides), Tomat (Solanum lycopersicum), Jambu (Psidium guajava), Jarak (Jatropha curcas), Katuk (Sauropus androgynous), Meniran (Phyllanthus niruri), Miyana (Coleus scutellaroides) dan Patika Kebo (Euphorbia hirta). Penelitian ini adalah penelitian pendahuluan sehingga data ini masih sangat muda dan butuh dikembangkan.

\section{DAFTAR PUSTAKA}

Arrizqiyani T, Sri S, Mila M. 2018. Aktivitas antibakteri daging buah dan daun pala (Myristica fragrans) terhadap Escherichia coli. Jurnal Vokasi Kesehatan. 4(2):81-84

Jumiarni, WO., Oom K. 2017. Eksplorasi Jenis dan Pemanfaatna Tumbuhan Obat pada Masyarakat Suku Muna di Permukiman Kota Muna. Trad. Med. J. 22(1): 45-56

Kementerian Perdagangan. 2017. Info komoditi tanamn obat. Badan Pengkajian dan Pengembangan Perdagangan Kementerian Perdagangan Republik Indonesia

Mardiyaningsih A, Resmi A. 2014. Development of pandanus amaryllifolius roxb leaves extract as antibacterial agent. Pharmaciana. 4(2): 185-192 
https://jurnal.unsulbar.ac.id/index.php/saintifik

Nurrani L. 2013. Pemanfaatan Tradisonal Tumbuhan Alam Berkhasiat Obat oleh Masyarakat disekitar Cagar Alam Tangale. Info BPK Manado. 3(1): 1-22

Nugroho H, Esti R, Dimas BWP, Rendro W. 2016. The Influence of Sambiloto Leaf Extract (Andrographis paniculata Ness.) toward Killing Power Bacteria Leptospira sp. Media litbangkes. 26(2): 77-84

Nuyani S, Saptono P, Darwani. 2017. Pemanfaatan Ekstrak Daun Jambu Biji (Psidium guajava Linn) Sebagai Antibakteri dan Antifungi. Jurna Teknologi Laboratorium. 6(2): 41-45

Octaviani M, Haiyul F, Erenda Y. 2019. Antimicrobial Activity of Ethanol Extract of Shallot (Allium cepa L.) Peels Using the Disc Diffusion Method. Pharmaceutical Sciences and Research. 6(1): 62-68

Peka-Indonesia. 2015. Tumbuhan obat Halimun. http://peka-indonesia.org/wp-content/uploads/2015/02/buku$\underline{\text { tanaman-obat.pdf }}$

Ridwan Y, Yasmine QA. 2007. Phytochemical and Anthelmintic Activity against Chicken Tapeworm of Painted nettle (Coleus blumei. benth) varieties In Vitro. Jurnal Protein. 14(1): 17-20

Sikumalay A, Netti S, Machdawaty M. 2016. Efek Antibakteri dari Rebusan Daun Sambiloto (Andrographis paniculata Nees) dan Produk Herbal Sambiloto Terhadap Staphylococcus Aureus. Jurnal Kesehatan Andalas. 5(1): 196-200

Syamsiah. 2014. Eksplorasi Tumbuhan Obat Tradisonal Di Kecamatan Pamboang Kabupaten Majene Sulawesi Barat. Jurnal Bionature. 15(2): 127-136

Widiyati A, Prihadi TH. 2007. Dampak Pembangunan Waduk terhadap Kelestarian Biodiversity. Media Akuakultur. 2(2). 